\title{
Distributions, stoichiometric patterns and cross-shelf exports of dissolved organic matter in the East China Sea
}

\author{
J.-J. Hung ${ }^{\mathrm{a}, *}$, C.-H. Chen ${ }^{\mathrm{a}}$, G.-C. Gong ${ }^{\mathrm{b}}$, D.-D. Sheu ${ }^{\mathrm{a}}$, F.-K. Shiah ${ }^{\mathrm{c}}$ \\ a Institute of Marine Geology and Chemistry, National Sun Yat-Sen University, Kaohsiung, Taiwan, ROC \\ ${ }^{\mathrm{b}}$ Department of Oceanography, National Taiwan Ocean University, Keelung, Taiwan, ROC \\ ${ }^{\mathrm{c}}$ Institute of Oceanography, National Taiwan University, Taipei, Taiwan, ROC
}

Accepted 12 October 2002

\begin{abstract}
This paper sets out to elucidate distributions, stoichiometric patterns and cross-shelf exports of dissolved organic matter (DOM) in the East China Sea (ECS). Surface distributions of dissolved organic carbon (DOC) in the ECS varied spatially, ranging from 85 to $120 \mu \mathrm{M}$ in the China Coastal Water (CCW), from 75 to $85 \mu \mathrm{M}$ in the Kuroshio Water $(\mathrm{KW})$, and from 60 to $70 \mu \mathrm{M}$ in the upwelling water. DOC concentrations in most regions of the shelf mixed water (SMW) were between 72 and $85 \mu \mathrm{M}$. Temporal variations were insignificant with the exception of the CCW, where the concentration was greater in summer and autumn than in spring and winter. Spatial patterns of dissolved organic nitrogen (DON) and dissolved organic phosphorus (DOP) were less variable in the spring season, ranging from 6 to $9 \mu \mathrm{M}$ for DON and 0.15 to $0.25 \mu \mathrm{M}$ for DOP. The elemental ratios of DOC, DON and DOP are much greater than the Redfield ratio, ranging from 8.9 to 15.3 for $\mathrm{C} / \mathrm{N}$, from 19 to 83.6 for $\mathrm{N} / \mathrm{P}$ and from 200 to 853 for C/P. Such ratios also showed a general increase with depth. However, the slopes of linear regression of DOM pairs become smaller and were about 8.4 for $\Delta \mathrm{DOC} / \Delta \mathrm{DON}, 19$ for $\Delta \mathrm{DON} / \Delta \mathrm{DOP}$ and 129 for $\Delta \mathrm{DOC} / \Delta \mathrm{DOP}$, suggesting the possible ratios derived from the recently produced fraction. Vertical increases of ratios in DOM pairs may suggest that the recycling of DOP and DON is more rapid than that of DOC to overcome the biological overconsumption of DIC to DIN and DIP ( $\triangle$ NDIC: $\triangle N D I N: \triangle N D I P=1: 14.3: 129$ ), as the ratio of $\triangle \mathrm{POC} / \triangle \mathrm{PON}$ (6.74) approaches the Redfield ratio in the euphotic zone. Degradation rates of DOC and DOP are variable with water types and are generally greater for the $\mathrm{CCW}$ than for the $\mathrm{KW}$, suggesting the different lability of DOM in various waters. The residence times of bulk DOC, DON, and DOP in the shelf are about $1.10,0.98$, and $0.92 \mathrm{yr}$, respectively, which are close to the ranges of the mean residence time of shelf water reported previously, suggesting that there is little to no export off the shelf. Finally, total inputs are closely balanced by total outputs for bulk DOC, DON, and DOP in the ECS shelf, if temporal variations of DON and DOP are negligible. However, net exports across the shelf are highly probable if only labile and semi-labile DOC $\left(3.8 \pm 0.6 \times 10^{12} \mathrm{~g} \mathrm{Cyr}^{-1}\right)$, DON $\left(482 \pm 160 \times 10^{9} \mathrm{~g} \mathrm{~N} \mathrm{yr}^{-1}\right)$, and DOP $\left(37.5 \pm 18.5 \times 10^{9} \mathrm{~g} \mathrm{Pyr}^{-1}\right)$ are involved in the budget calculation. The ECS shelf is likely to be a small source of degradable DOM for oceanic waters.
\end{abstract}

(C) 2003 Elsevier Science Ltd. All rights reserved.

\footnotetext{
*Corresponding author. Tel.: + 886-7-5255147; fax: + 886-7-5255130.

E-mail address: hungjj@mail.nsysu.edu.tw (J.-J. Hung).
} 


\section{Introduction}

The role of DOC (for abbreviations refer Table 1) in the marine carbon cycle has received considerable attention over the last two decades. The studies, however, have focused largely on open oceans. Although the importance of marginal seas to the marine carbon cycle is recognized (Walsh, 1991; Walsh et al., 1988; Wollast, 1991; Biscaye and Anderson, 1994), fewer DOC studies (Guo et al., 1995; Chen et al., 1996; Bates and Hansell, 1999; Alverez-Salgado et al., 2001) have been conducted to elucidate the fate and cycling of organic carbon in marginal seas. This is possibly due to the multiple sources and more complex processes involving organic carbon in the marginal seas. The situation is particularly true for the East China Sea (ECS) continental margin where a large shelf interacts with large rivers and the Kuroshio Current, respectively, from western and eastern boundaries. Very few results related to ECS organic carbon biogeochemistry have been reported from a shelf-wide consideration.

DON and DOP are two organic nutrients involved in the marine carbon cycle. Several processes (e.g., phytoplankton excretion, zooplankton grazing, POM solubilization, atmospheric deposition and riverine flux) are responsible for the introduction of DON, DOP, and DOC into oceans (Connolly et al., 1992; Wotton, 1994; Orrett and Karl, 1987; Anderson and Williams, 1998; Hansell and Carlson, 1998). Some DON and DOP can be used directly by primary producers under certain circumstances, but in most situations they are degraded to release inorganic nutrients as bacteria consume DOC during growth (Connolly et al., 1992; Wotton, 1994). DON and DOP may play important roles in nutrient budgets and carbon cycles in oligotrophic oceans where inorganic nutrients are devoid in the euphotic zone (Thomas et al., 1971; Jackson and Williams, 1985; Vidal et al., 1999). However, it is not clear whether DON and DOP also can be important in carbon cycles in marginal seas where surface inorganic nutrients are not completely depleted.

The ECS is one of the largest marginal seas worldwide, receiving enormous rates of fresh-
Table 1

Acronyms used in this study

\begin{tabular}{ll}
\hline Acronyms & Water mass and chemical properties \\
\hline CCW & China Coastal Water \\
KW & Kuroshio Water \\
SMW & Shelf Mixed Water \\
YSMW & Yellow Sea Mixed Water \\
DIC & Dissolved inorganic carbon \\
DIN & Dissolved inorganic nitrogen \\
DIP & Dissolved inorganic phosphorus \\
DOC & Dissolved organic carbon \\
DON & Dissolved organic nitrogen \\
DOP & Dissolved organic phosphorus \\
DOM & Dissolved organic matter \\
POC & Particulate organic carbon \\
PON & Particulate organic nitrogen \\
TDN & Total dissolved nitrogen \\
TDP & Total dissolved phosphorus \\
\hline
\end{tabular}

water $\left(>885 \mathrm{~km}^{3} \mathrm{yr}^{-1}\right)$, suspended matter $(>1.4 \times$ $10^{9}$ ton $\mathrm{yr}^{-1}$ ) and nutrients from the Changjiang and Huangho (Milliman and Meade, 1983). The ECS shelf receives a larger amount of nutrients from the upwelled Kuroshio subsurface water, occurring on the southern ECS shelf break off northeastern Taiwan (Wong et al., 1991; Liu et al., 1992; Li, 1994; Chen, 1996). As a result, the ECS shelf may be one of the most productive marginal seas in the world. The primary productivity, however, is temporally and spatially variable on the southern ECS shelf and the spatial pattern is generally coincident with nutrient distributions (Gong et al., 2000). The annual mean value over the whole southern ECS shelf is $200 \pm 30 \mathrm{~g}$ $\mathrm{C} \mathrm{m}^{-2} \mathrm{yr}^{-1}$ (Gong et al., 2000). Although the major source of DOM in oceanic water is likely related to primary productivity (Carlson et al., 1994; Norrman et al., 1995), the relationship between primary productivity and DOM distributions in marginal seas is not well known. Shiah et al. (2000) reported high bacterial biomass, production, and average turnover rates in coastal and upwelled waters but lower rates in the Kuroshio Water from the southern ECS. The bacterial processes are all positively correlated with the POC inventory, but their relations to DOC are not explored (Shiah et al., 2000). Hung et al. (2000) reported DOC and POC distributions 
from a transect of southern ECS and suggested that DOC and POC are derived from both biological and terrestrial sources, but the contributions vary spatially.

New productivity in the ECS was reported to range from $17 \%$ to $82 \%$ of total primary productivity (Chen et al., 1999). Apparently, regenerated productivity was sometimes significant in the ECS shelf. The cycling of dissolved organic matter can result in nutrient regeneration and contribute to the primary productivity. Thus, it is worth knowing the contribution of DON and DOP remineralization to the primary productivity in the ECS. Besides, DOC not recycled over the broad shelf may be exported from the ECS. The intensive exchange between shelf water and the Kuroshio may facilitate DOC export. Understanding the shelf DOC export may also enhance our knowledge of the role of the marginal sea in the marine carbon cycle. Therefore, in this study, we examine the spatial and temporal distributions of DOC, stoichiometric relationships for DOC, DON, and DOP, and degradation rates of DOC and DOP in the ECS. In addition, the cross-shelf exports of DOC, DON, and DOP from the ECS continental shelf are investigated.

\section{Methods}

Samples were collected on board the $R / V$ Ocean Researcher I during cruises ORI-449 (05/2-15/ 1996), 493 (07/08-13/1997), 511 (12/19-30/1997), $521(06 / 30-07 / 05 / 1998)$, and $532(10 / 29-11 / 06 /$ 1998). The cruises covered all seasons. The sampling stations for each cruise are shown in Fig. 1. Most cruises occupied numerous stations to cover the whole continental shelf of the ECS, but only five stations were occupied to take samples for the experiment of DOM degradation during Cruise 493. Seawater samples were collected with cleaned Go-Flo bottles (20-1) mounted on a CTD/ rosette that recorded the temperature and salinity profiles.

Dissolved and particulate organic matter samples were separated by filtration through precombusted 25-mm GF/F (Whatman) glass-fiber filters immediately after collecting the seawater,

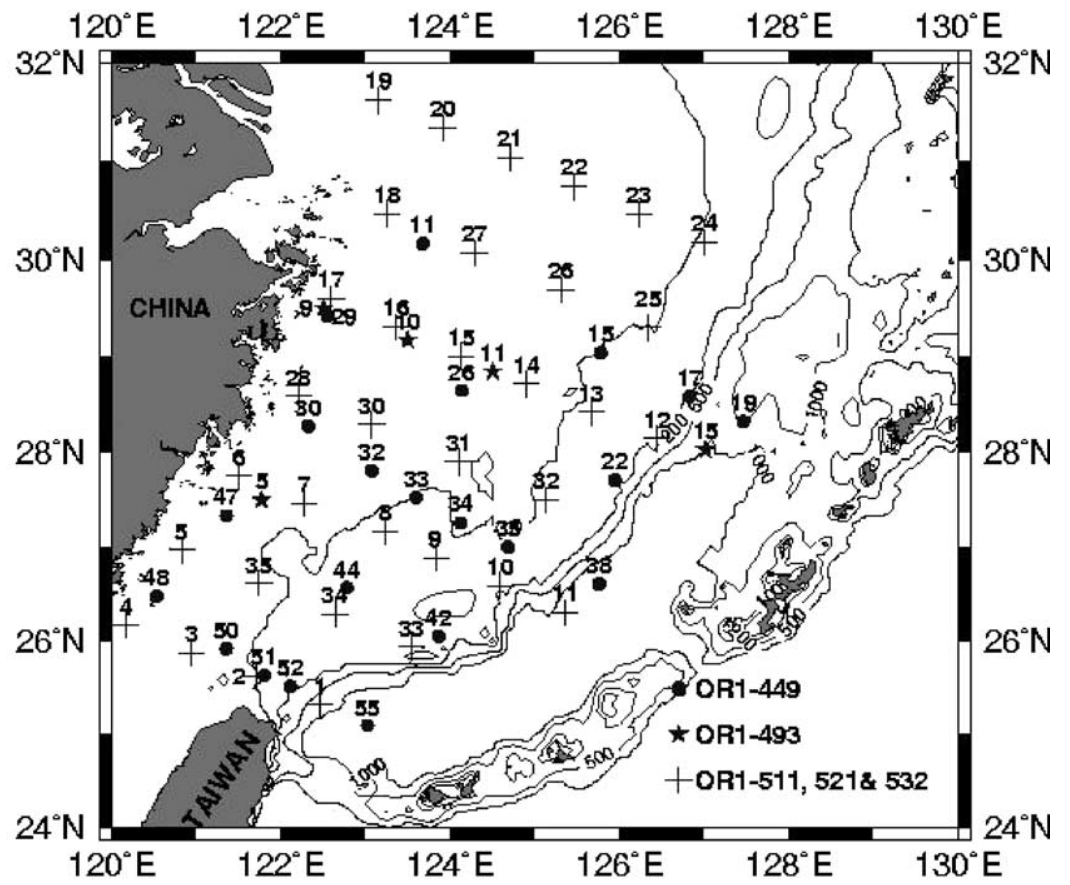

Fig. 1. The map of study area and sampling locations. 
according to the procedures developed by Hung and Lin (1995). The filters were sealed in cleaned petri-dishes and stored in a freezer during transfer to the laboratory. The filters were then dried in an oven at $60^{\circ} \mathrm{C}$ for POC determination. The filtered water was acidified with $\mathrm{HCl}(0.4 \%, \mathrm{v} / \mathrm{v})$ and stored at $4{ }^{\circ} \mathrm{C}$ for DOC measurements.

DOC was measured with the method of hightemperature catalytic oxidation using the Shimadzu TOC-5000 analyzer (Hung and Lin, 1995). The muffled $\left(850^{\circ} \mathrm{C}, 2 \mathrm{~h}\right) \mathrm{CuO}$ wire was placed on the top of the catalyst to enhance the peak shape and reproducibility of peak integration (Sharp, 1993). Before standard and sample measurements, catalysts $\left(\mathrm{Pt} / \mathrm{Al}_{2} \mathrm{O}_{3}\right)$ were thoroughly conditioned by injecting DOC-free Milli-Q water until a low and constant signal was detected. The instrument blank was estimated to be $10 \mu \mathrm{M} \mathrm{C}$ according to the procedure of Benner and Strom (1993). DOC in seawater was analyzed by placing $20 \mathrm{ml}$ of acidified seawater in a Pyrex glass test tube and purged with ultrapure air for $8 \mathrm{~min}$ to remove dissolved $\mathrm{CO}_{2}$. One-hundred microliter aliquots of decarbonated standard or seawater sample were injected at least five times into the oxidation column. Abnormal signals (usually low and high) were automatically rejected to ensure that the standard deviation of repeated injections was $<2 \%$. The relative difference between our measurements and recommended values was within the $\pm 4 \%$ and $\pm 10 \%$ limits, respectively, for stages 1 and 2 of the DOC intercomparison exercises ( $\mathrm{J}$. Sharp personal correspondence). DON was determined from the difference between dissolved inorganic nitrogen and total dissolved nitrogen (TDN) that was measured with the chemiluminence method using an instrument of Antek Models 771/720. DOP was determined from the difference between $\mathrm{PO}_{4}^{3-}$ and TDP (total dissolved phosphorus) that was measured with UV-persulfate oxidation and colorimetric method (Ridal and Moore, 1990). Dissolved inorganic nitrogen $\left(\mathrm{NO}_{3}^{-}+\mathrm{NO}_{2}^{-}\right.$, hereafter DIN) and $\mathrm{PO}_{4}^{3-}$ (hereafter DIP) were determined colorimetrically (Grasshoff et al., 1983) with a flow injection analysis method (Pai and Yang, 1990; Gong, 1992). The precision was better than $8 \%$ and $5 \%$, respectively, for TDN and TDP.
The experiments for DOM degradation in various seawaters were conducted using an incubation method. Surface water samples were taken from Cruise 493 during summer (07/08-13/ 1997). A large volume ( 301) of water was filtered through precombusted $\mathrm{GF} / \mathrm{C}$ filters $(\sim 1.2 \mu \mathrm{m}$ pore size) and then divided into numerous 1-1 polycarbonate bottles. Subsequently, the bottles were stored at room temperature $\left(\sim 25^{\circ} \mathrm{C}\right)$ under totally dark conditions. Duplicated bottles were opened for DOC and DOP determination according to the described procedures at various times of incubation. Bacterial abundance was not monitored during the course of experiment. The incubation lasted over $270 \mathrm{~d}$ for each water sample.

Particulate organic carbon (POC) and nitrogen (PON) were determined during the 449 cruise. POC and PON were determined with a $\mathrm{C} / \mathrm{N} / \mathrm{S}$ analyzer (Fisons NCS 1500) after carbonate was removed by placing the filtered particulate matter in a precombusted silver boat, adding a few drops of $2 \mathrm{~N} \mathrm{HCl}$ on the filter, and oven drying at $50^{\circ} \mathrm{C}$ for $48 \mathrm{~h}$. The silver boat was then wrapped and placed in an autosampler to determine POC and PON concentrations. The blank value attributed to the GF/F filter and silver boat was deducted from the raw value of a sample concentration. The sampling and measuring precisions of POC and PON were $\pm 0.3 \mu \mathrm{M} \mathrm{C}$ and $\pm 0.2 \mu \mathrm{M} \mathrm{N}( \pm 1 \sigma)$, respectively, as evaluated from 8 replicate samples from the same depth.

\section{Results and discussion}

\subsection{Hydrography}

The hydrographic settings of the ECS are displayed largely in Fig. 2. Briefly, the major hydrographic features are the characteristics of waters mixed from the CCW, the SMW, the KW and/or the Yellow Sea Mixed Water (YSMW).

The CCW is a mixture of the Changjiang freshwater and the SMW, characterized by a low salinity $(<32)$ (Fig. 3). The water flows southward predominantly along the China coast during the winter season, but a part of $\mathrm{CCW}$ also flows 


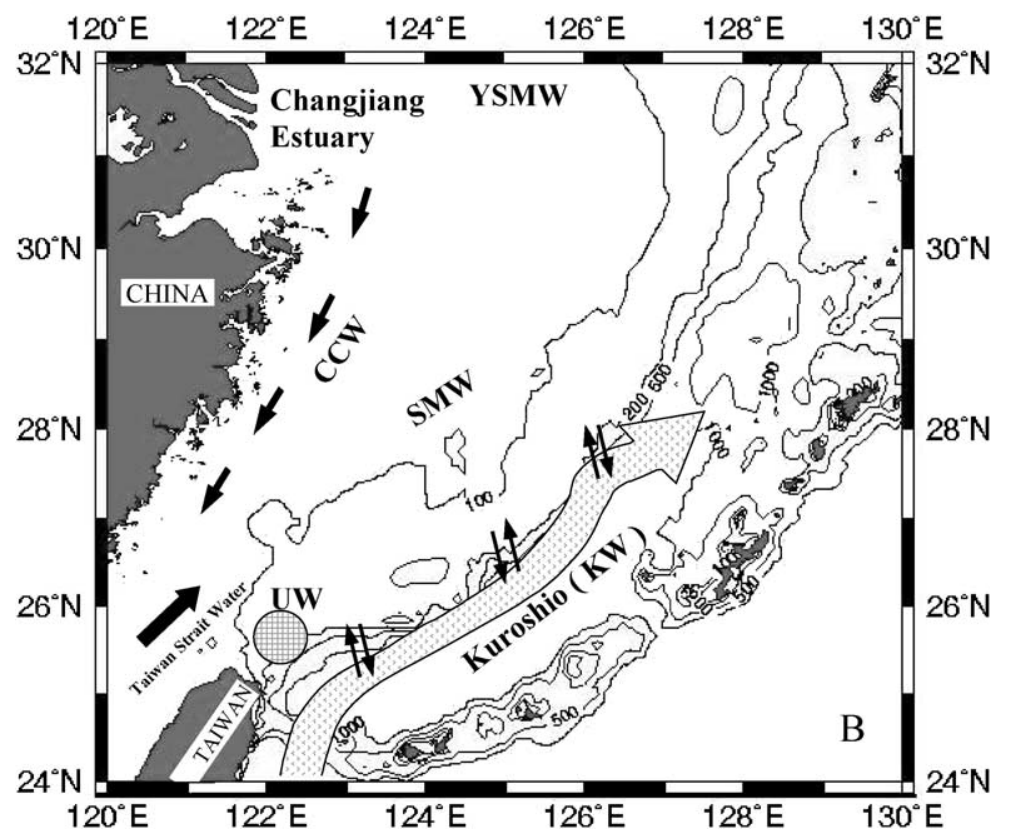

Fig. 2. Schematic representation of various waters in the East China Sea.

northeastward from the Changjiang River mouth during the summer season (Beardsley et al., 1985; Gong et al., 1996). Most stations along the China coast are obviously within the CCW (Figs. 1 and 2). Seasonal variations of salinity are apparently stronger in the CCW than in other waters (Fig. 3). The SMW is derived from mixing among the CCW, the Taiwan Strait Water, the Kuroshio surface water and the Kuroshio subsurface water. Water temperature and salinity of the SMW are generally in the range between the $\mathrm{CCW}$ and the $\mathrm{KW}$ (Fig. 4). The KW is characterized by high temperature and salinity (Fig. 4), but low nutrients in the surface layer. The striking reversed S-shape in $\mathrm{T}-\mathrm{S}$ relationship (Fig. 4) shows a maximum salinity $>34.7$ that is also a characteristic of the North Pacific subtropical water (Nitani, 1972). This KW flows northward along the east coast of Taiwan and results in a persistent upwelling from the Kuroshio subsurface onto the ECS shelf occurring around the southern ECS off northeast Taiwan (St. 52 in the 449 cruise) induced by a topographic change. The upwelled water is laden with nutrients and may influence carbon biogeochemistry as well. The YSMW forms from mixing between the Yellow Sea Coastal Water of the ECS and the KW. This water is generally confined to the northern ECS with lower temperature and salinity, and the occupied area is subjected to seasonal and annual variability (Chern and Wang, 1990; Gong and Liu, 1995).

\subsection{Distributions of DOC, DON, and DOP}

Seasonal distributions of DOC in the ECS surface water are shown in Fig. 5. The distributions vary temporally and spatially. The concentration is relatively high in the $\mathrm{CCW}$, ranging from about $85 \mu \mathrm{M}$ in the southern China coast (26$30^{\circ} \mathrm{N}$ ) during autumn and winter to $110-120 \mu \mathrm{M}$ close to the Changjiang Estuary $\left(30.5-32^{\circ} \mathrm{N}, 123-\right.$ $\left.124^{\circ} \mathrm{E}\right)$ during summer. The elevated DOC concentrations may be derived mostly from terrestrial inputs and less from in situ production, as the $\mathrm{CCW}$ is sometimes low in primary productivity due to photo limitation (Gong et al., 2000). The concentration is higher in summer and autumn seasons than in winter and spring seasons, probably resulting from differing strengths of freshwater (terrestrial) and nutrient (productivity) 

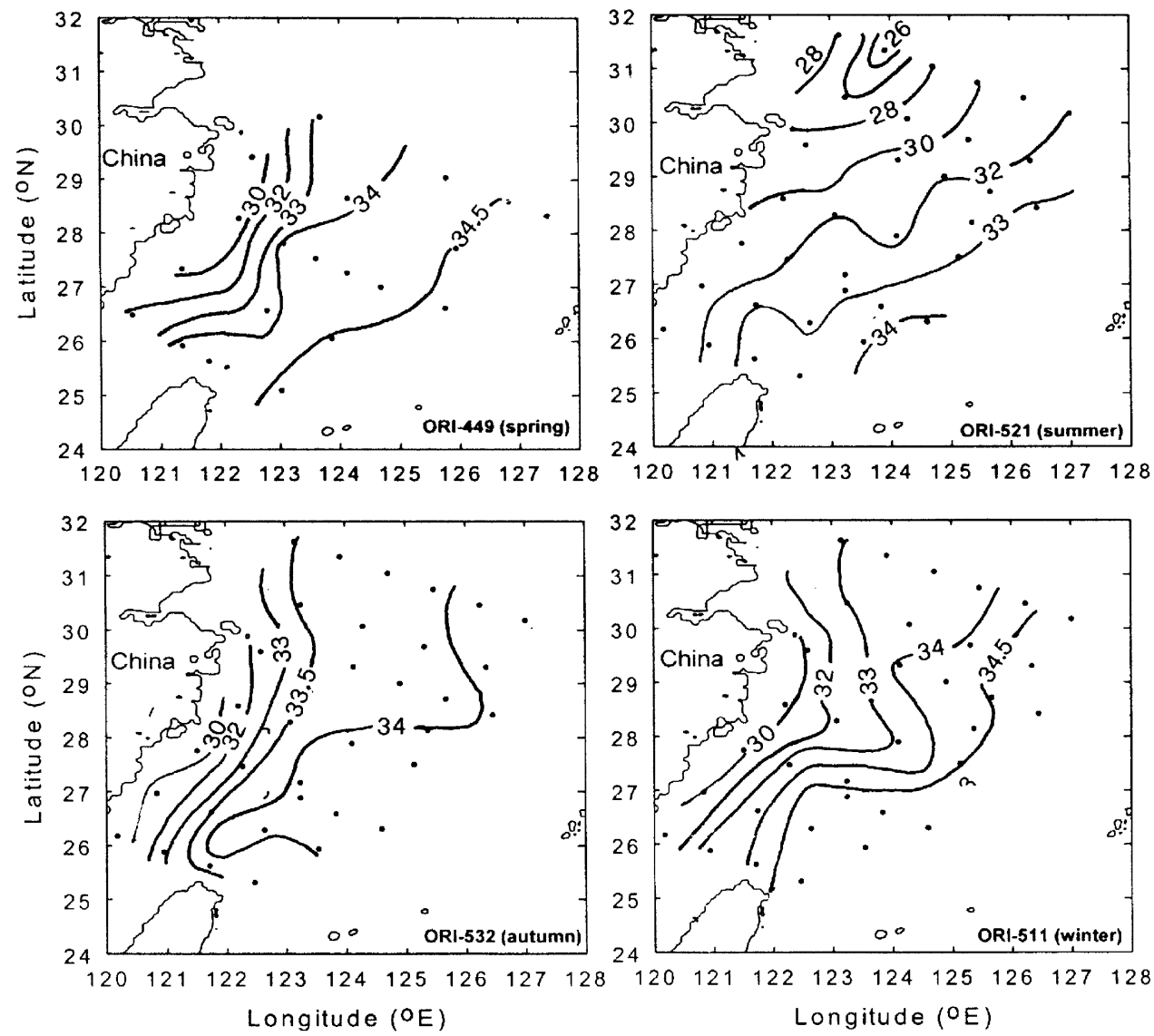

Fig. 3. Distributions of salinity in surface water during various seasons.

inputs. The concentration is lower $(72-85 \mu \mathrm{M})$ in the SMW than in the CCW. This may arise from the decrease of terrestrial inputs and imbalance between biological production and bacterial consumption, in addition to the mixing process. Seasonal variations are significant only in the area close to the Changjiang mouth. Although far away from terrestrial sources, DOC concentrations remain fairly high in the surface layer of $\mathrm{KW}$ $(75-85 \mu \mathrm{M})$ with frequent appearance of a subsurface maximum at $40-80 \mathrm{~m}$, just below the mixing layer. Such a distribution pattern has been discussed by Hung et al. (2000) and was attributed primarily to physical stability of the stratified water column and a lower rate of microbial consumption. No significant difference is found between seasons for the $\mathrm{KW}$, which may result from little influence by terrestrial inputs or primary production during various seasons. The lowest concentrations of DOC $(60-70 \mu \mathrm{M})$ were always found in the upwelled water. The upwelling brought in DOC-poor water $(55-60 \mu \mathrm{M})$ from the Kuroshio subsurface and diluted the ambient DOC concentration. These biophysical processes are likely responsible for no correlation $(r=0.192, p>0.1)$ between DOC and primary productivity measured by G.-C. Gong et al. (2003) in the ECS.

Surface distributions of DON and DOP derived from Cruise 449 in the ECS are displayed in Fig. $6 \mathrm{a}$ and $\mathrm{b}$, respectively. Spatial distributions range from 6 to $9.6 \mu \mathrm{M}$ for DON and from 0.05 to $0.25 \mu \mathrm{M}$ for DOP. Relatively higher concentrations of DON $(7.7-9.6 \mu \mathrm{M})$ and DOP $(>0.2 \mu \mathrm{M})$ are found in the $\mathrm{CCW}$. Intermediate ranges of DON $(6-7 \mu \mathrm{M})$ and DOP $(0.15-0.2 \mu \mathrm{M})$ 


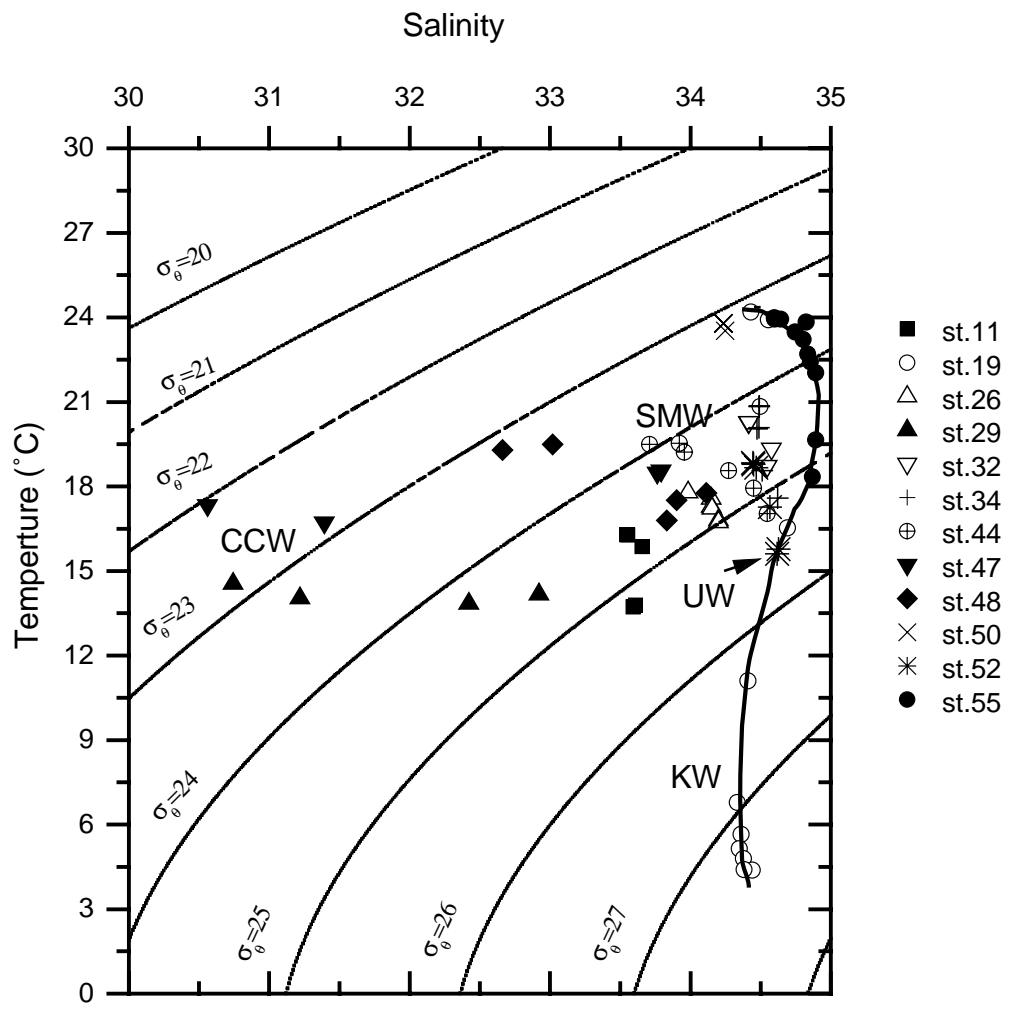

Fig. 4. Temperature-salinity plots for selected stations during Cruise 449. The reversed s-shape curve indicates T-S characteristics of the KW.

concentrations are present in the $\mathrm{KW}$. The lowest concentrations of DON $(\leqslant 5 \mu \mathrm{M})$ and DOP $(\leqslant 0.18 \mu \mathrm{M})$ are found in the upwelled water. Such surface concentration ranges are not significantly different from those reported previously for North Pacific surface waters by Walsh (1989); (DON: 5$10 \mu \mathrm{M}$; DOP: $0.37 \mu \mathrm{M})$, Maita and Yanada (1990); (DON: $1-10 \mu \mathrm{M}$ ), Ridal and Moore (1992); (DOP: 0.17-0.38 $\mu \mathrm{M}$ ), and Abell et al. (2000); (TON: 5$6 \mu \mathrm{M}$; TOP: $0.1-0.35 \mu \mathrm{M})$. DON is apparently the most abundant nitrogen species ranging from $20 \%$ to $99 \%$ of TDN in surface water $(<150 \mathrm{~m})$, but can be as low as $8 \%$ of TDN in the Kuroshio deep water. DOP is also generally more abundant than DIP, ranging from $5.5 \%$ to $68 \%$ of TDP in surface water $(<150 \mathrm{~m})$, and is as low as $2 \%$ of TDP in the Kuroshio deep water.

Vertical DOM distributions in various water types during spring (Cruise 449) are displayed in Fig. 7. Concentrations of DOC, DON, and DOP decrease with depth to about $61-74,4.2-5.5$, and $0.06-0.08 \mu \mathrm{M}$, respectively, in the CCW (Fig. 7a), the SMW (Fig. 7b) and the upwelled water (Fig. 7c), and to about 51, 3.0, and $0.06 \mu \mathrm{M}$, respectively, in the KW (Fig. 7d). Concentrations of DOM in the Kuroshio deep water may reflect the refractory fractions. Such distributions are similar to those previous reports in marginal seas (Hopkinson Jr. et al., 1997; Sanders and Jickells, 2000).

In addition to terrestrial inputs, complicated biological processes are involved in the release of DON and DOP (Sanders and Jickells, 2000). The greater inorganic nutrients in marginal seas are not necessarily responsible for higher production of DON and DOP. DON and DOP are inversely correlated (data not shown here) with DIN and DIP in the ECS if a few data with particularly high DIN concentrations in the CCW are excluded. There is also no clear relationship between DON 

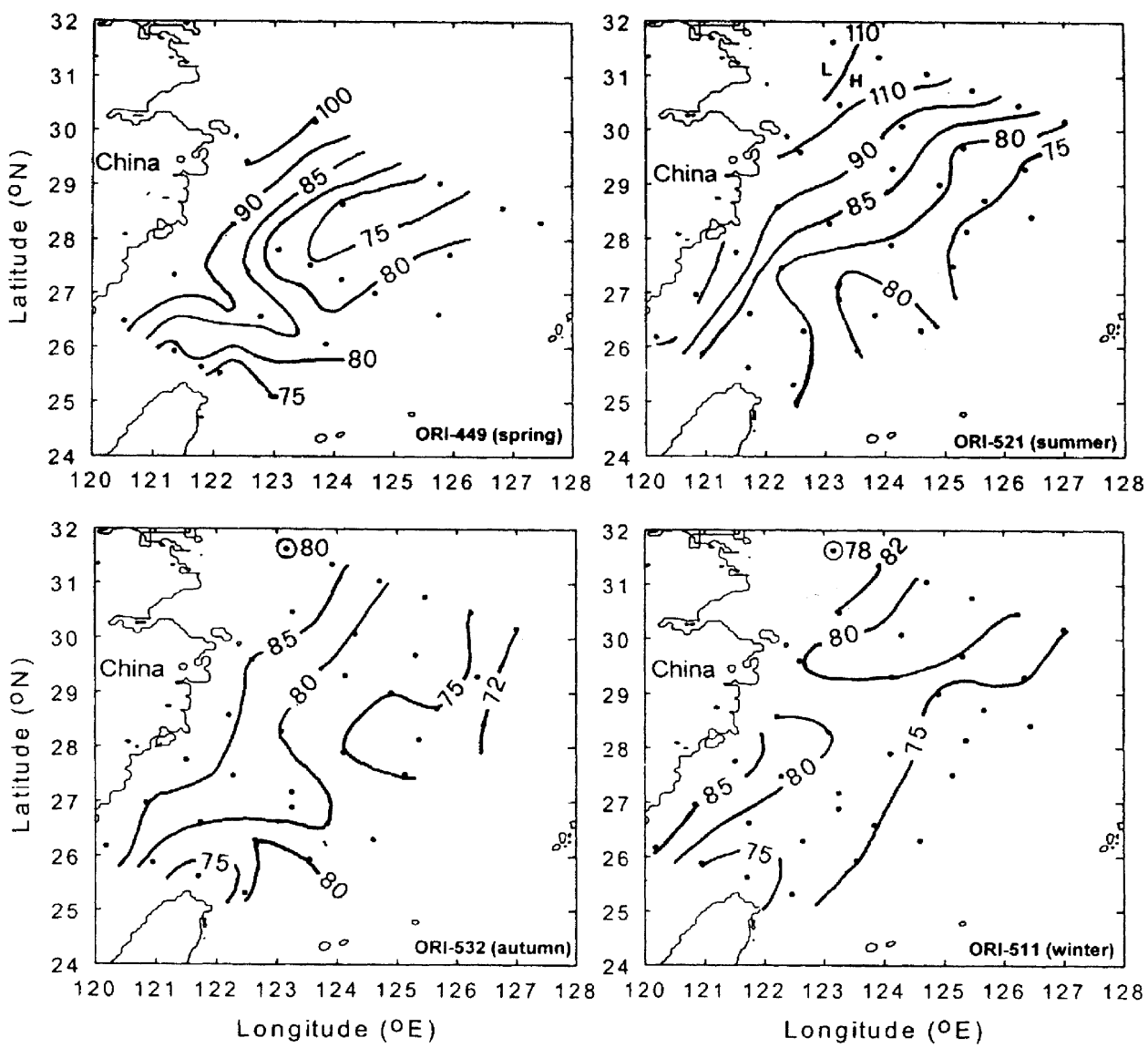

Fig. 5. Spatial and temporal distributions of DOC in the surface layer of East China Sea.

(DOP) and primary productivity (PP), although there is a reversed trend between integrated $P P$ (IPP) and integrated DON or DOP (IDON or IDOP). Processes related to DOC dynamics are likely to regulate DON and DOP distributions in the ECS as well. Temporal variations of DON and DOP are not known at this moment, although we speculate little variation in the ECS.

Since marine DOM is an important substrate for bacterial growth, it is worth knowing the relationship between DOM distributions and bacterial dynamics. Data derived from Cruise 449 show that depth integrated bacterial production (IBP; $3-13 \mathrm{mg} \mathrm{C} \mathrm{m}^{-2} \mathrm{~d}^{-1}$ ) is positively correlated with depth integrated DOC (IDOC; 84$197 \mathrm{mmol} \mathrm{C} \mathrm{m}^{-2}$ ) and DON (IDON; 6-17 mmol $\mathrm{N} \mathrm{m}^{-2}$; Fig. 8). However, the relationship for IBP vs. depth-integrated DOP (IDOP; 0.08-0.42 mmol
$\mathrm{P}^{-2}$ ) is not significant, primarily due to the data derived from Station 11 located near the Changjiang mouth. There, a high value of IBP is accompanied with a very low IDOP inventory. Both BP and DOM are integrated mostly from whole water column for shelf waters but from the euphotic zone $(<120 \mathrm{~m})$ for the KW. The relation between IBP and IDOP becomes positively correlated $(R=0.883 ; p<0.01)$ when this datum is excluded (Fig. 8). Shiah et al. (1999, 2000) suggested that bacterial growth in the ECS shelf was interactively controlled by temperature and substrate (i.e. DOM) supply during cold seasons (i.e. winter and spring). Positive correlation was significant between BP and temperature (Shiah et al., 1999). Meanwhile, significant correlation (positive) was also present between DOC and temperature while temperature was greater than 

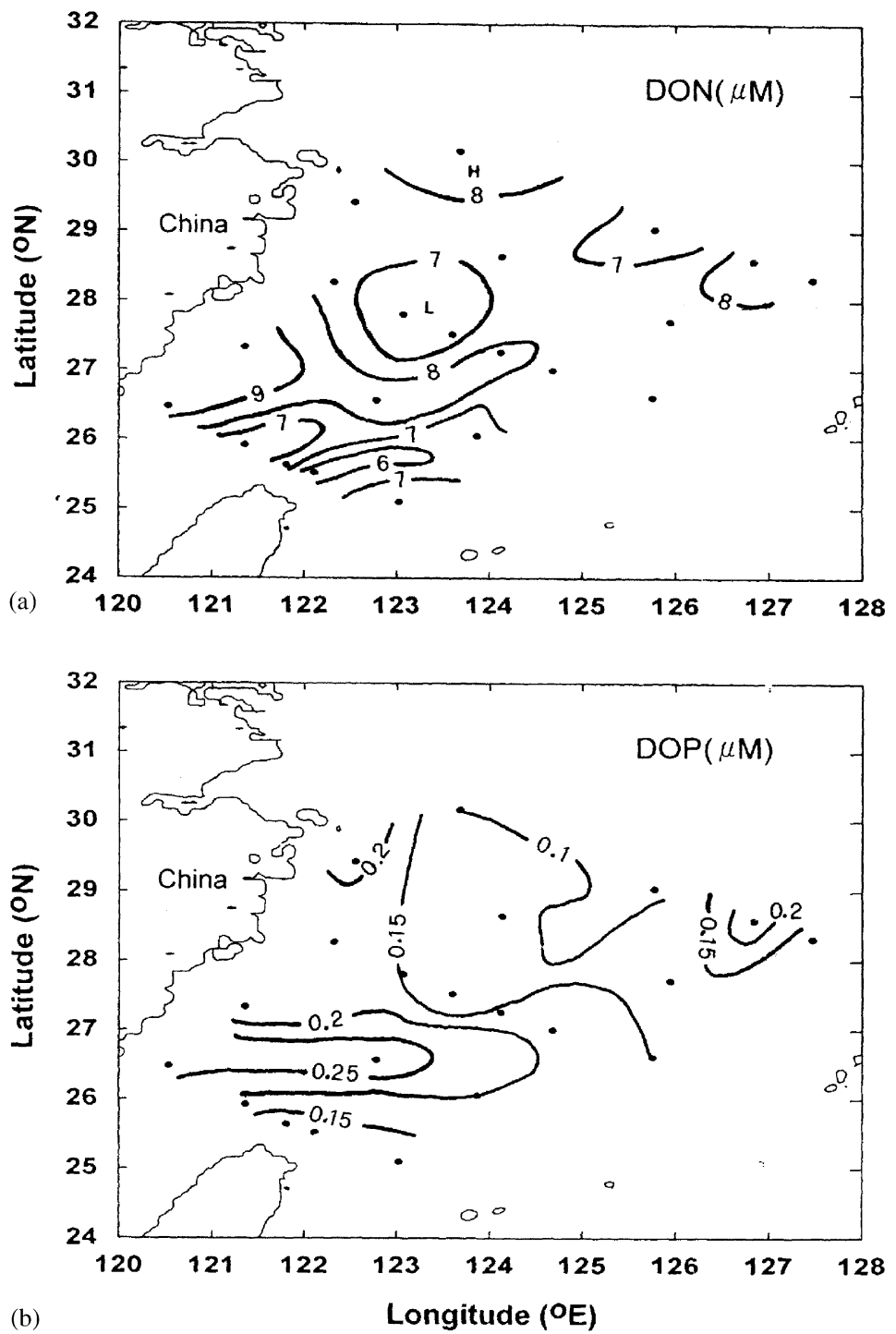

Fig. 6. Surface distributions of DON (a) and DOP (b) during the spring season (Cruise 449).

$14^{\circ} \mathrm{C}$ in the southern ECS (Hung et al., 2000). In this study (Cruise 449, later spring), positive correlations between IBP and IDOM may indicate that bacteria productivity is primarily controlled by temperature which is also positively correlated to DOC. Another explanation is that bacteria productivity is proportional to the abundance of bio-reactive DOM rather than total DOM. The greater BP may be accompanied by a larger amount of refractory DOM during the measurement in the shelf where refractory DOM is abundant. This possibility results in a positive relationship between IBP and IDOM.

Correlation is more significant between DOC and sigma-t $(R=-0.71, p<0.0001$; Fig. 9a) than between DOC and salinity $(R=-0.58, p<0.0001$; data not shown) for Cruise 449, implying the importance of vertical mixing in controlling DOC distributions. Those concentrations scattered from the linear relationship may result from the effects of biogeochemical processes superimposed on the mixing process. Correlation is much poorer 

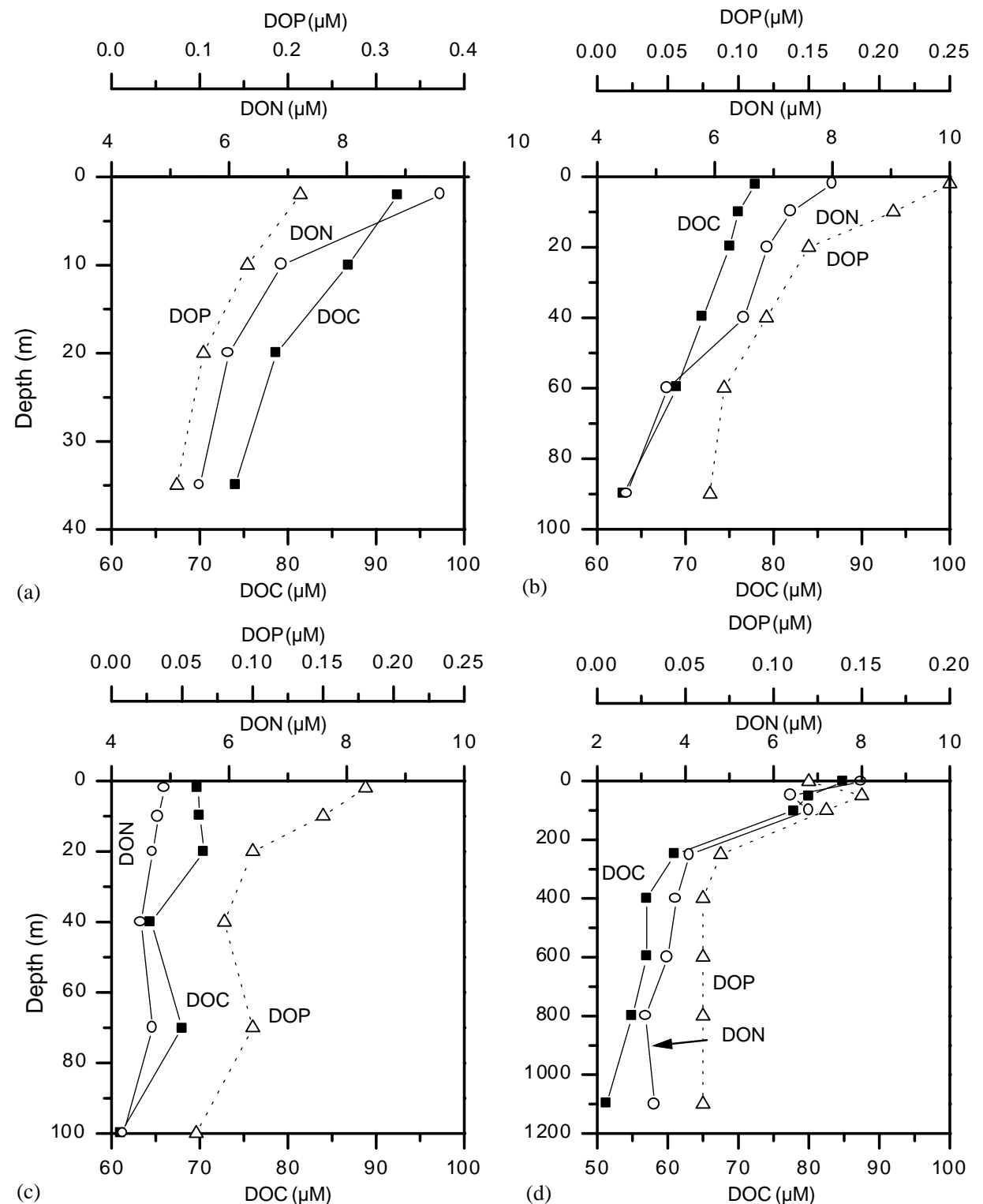

Fig. 7. Vertical profiles of DOC, DON and DOP in the CCW (7a, St. 47), the SMW (7b, St. 34), the upwelled water (7c, St. 52) and the KW (7d, St. 19) during Cruise 449.

between DON and sigma-t $(R=-0.47, p<0.0001)$ and between DOP and sigma-t $(R=-0.33$, $p<0.0001)$ than between DOC and sigma-t (Figs. 9a-c). Apparently, DOP and DON are more non-conservative than is DOC. This is consistent with a general consensus that the recycling of DOP and DON is more rapid than that of DOC
(Wotton, 1994; Hopkinson et al., 1997; Thomas et al., 1999).

\subsection{Stoichiometry of $D O C, D O N$, and $D O P$}

Simultaneous investigations of DOC, DON, and DOP were only made during Cruise 449 (spring 


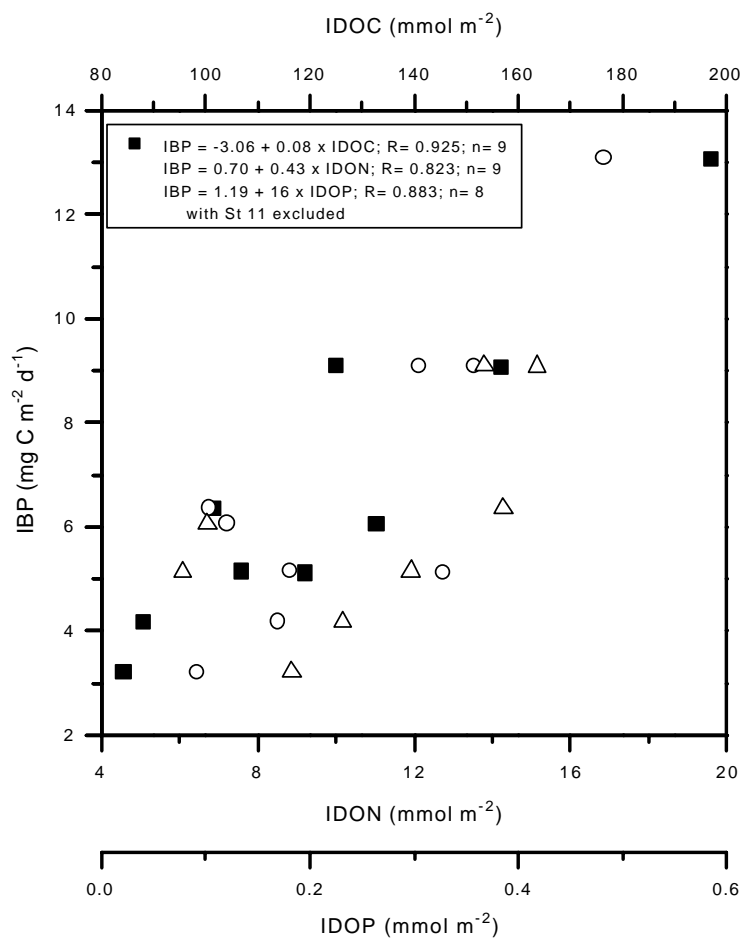

Fig. 8. Relation plots between depth-integrated bacterial production (IBP) and depth-integrated DOC (IDOC), depthintegrated DON (IDON) and depth-integrated DOP (IDOP).

season); therefore, the temporal variation of stoichiometry will not be discussed in this paper. The ratios of dissolved organic carbon, nitrogen and phosphorus in the ECS deviate significantly from the Redfield ratio $(\mathrm{C} / \mathrm{N} / \mathrm{P}=106 / 16 / 1)$. The elemental ratio ranges from 8.9 to 15.3 for $\mathrm{DOC} /$ DON, from 19 to 83.6 for DON/DOP and from 200 to 853 for DOC/DOP in the ECS shelf and the Kuroshio surface $(<150 \mathrm{~m})$ (Figs. 10a-c). Apparently DOM is considerably enriched in carbon relative to nitrogen and phosphorus, and nitrogen relative to phosphorus, compared to the Redfield value. Elemental ratios exhibit a large range for each water type; thus no clear spatial pattern of elemental ratios can be identified, although slightly greater values appear in the upwelled water and the $\mathrm{KW}$. Three ratios $(\mathrm{C} / \mathrm{N}, \mathrm{N} / \mathrm{P}, \mathrm{C} / \mathrm{P})$ all increase gently with depth to $100 \mathrm{~m}$ but increase markedly below to $100 \mathrm{~m}$ for the $\mathrm{KW}$ (Sts. 19 and 55), suggesting a preferential decay of DOP over DOC and DON, and DON over DOC in the ECS. Such

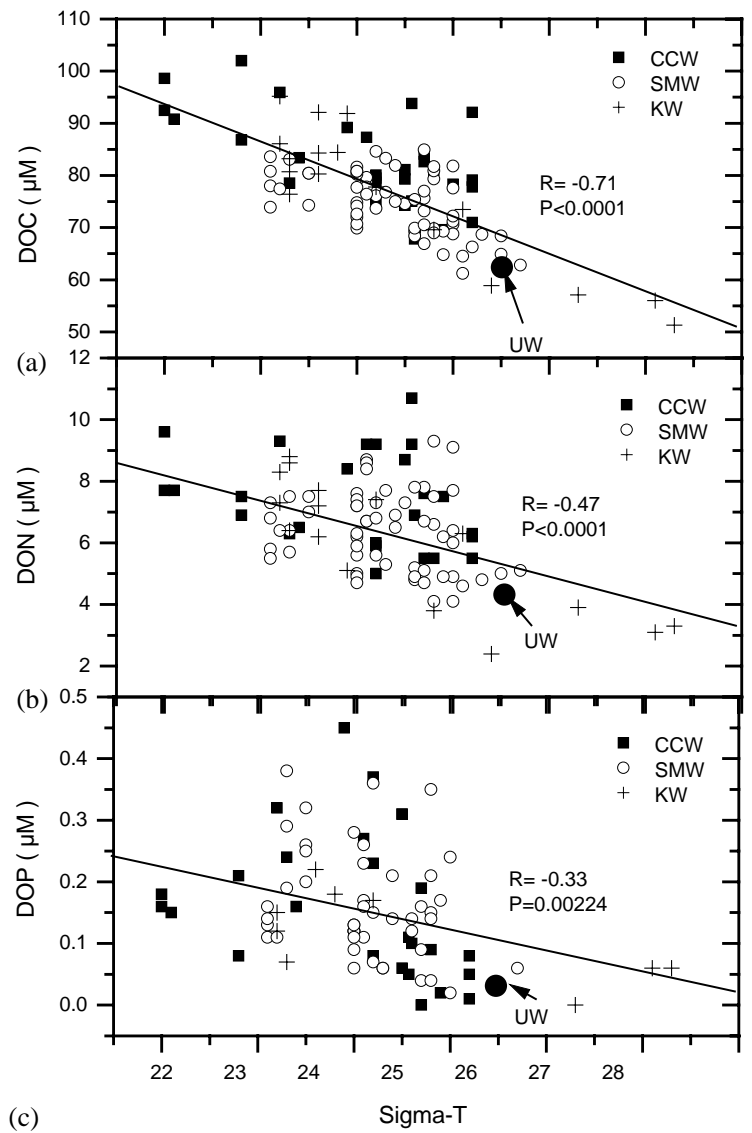

Fig. 9. Relation plots between sigma-t and DOC (a), DON (b) and DOP (c) for data collected from Cruise 449.

patterns of ranges and depth-increased ratios are consistent with previous results obtained from marginal seas and open oceans (Williams et al., 1980; Hopkinson et al., 1997; Vidal et al., 1999; Sanders and Jickells, 2000). Nevertheless, the bulk DOM in seawater generally consists of a biologically labile and a relatively refractory part that may be pronounced in the ECS continental margin. It is obvious that the elemental ratios of DOM do not necessarily conform to the Redfield ratio derived from biota. The slope of the DOC and $\mathrm{DON}$ data pairs increases $(\triangle \mathrm{DOC} / \triangle \mathrm{DON})$ may be more indicative of the $\mathrm{C} / \mathrm{N}$ ratio for the recently produced DOM. The slopes of $\triangle \mathrm{DOC} /$ $\Delta \mathrm{DON} \quad(8.4, \quad$ Fig. 10a), $\Delta \mathrm{DON} / \Delta \mathrm{DOP} \quad(19$, Fig. $10 \mathrm{~b})$ and $\Delta \mathrm{DOC} / \Delta \mathrm{DOP}(129$, Fig. $10 \mathrm{c})$ are much smaller than those of the elemental ratios, although the slopes are still greater than the 


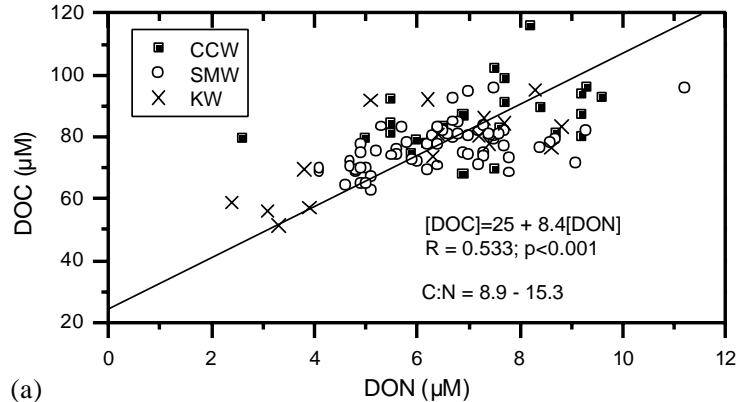

(a)

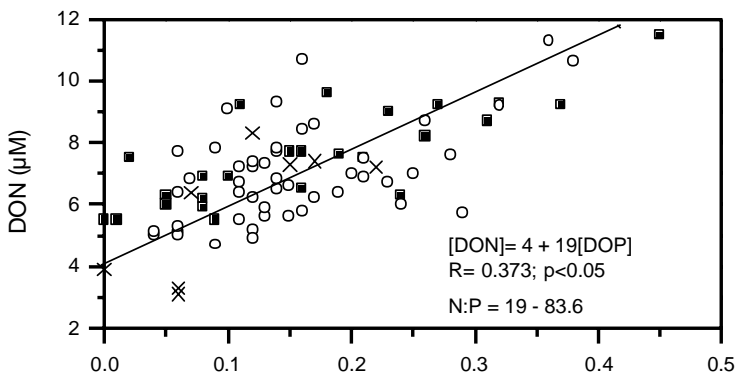

(b)

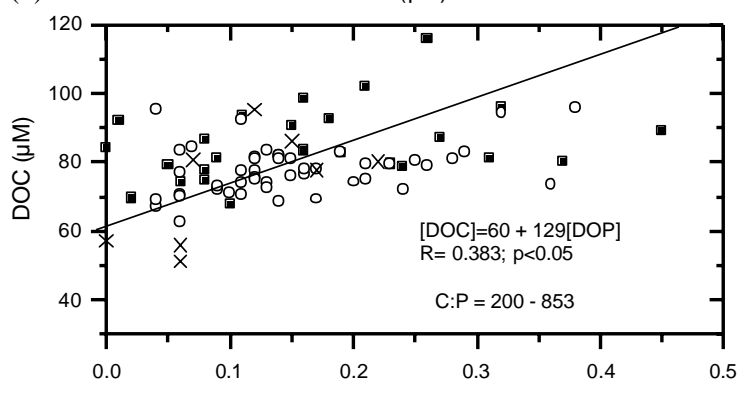

(c)

$\mathrm{DOP}(\mu \mathrm{M})$

Fig. 10. Ranges of elemental ratios and regression slopes of concentrations between DOC and DON (a), between DON and DOP (b) and between DOC and DOP (c) from data of Cruise 449 .

Redfield values. This also may indicate that even for recently produced DOM, carbon is still more enriched over nitrogen and phosphorus, and nitrogen over phosphorus.

The implication of DOM stoichiometry is that DON and DOP should be preferentially decomposed and the released inorganic $\mathrm{N}$ and $\mathrm{P}$ are incorporated into particulate organic materials during photosynthesis. This is also inferred from the slope of $\triangle \mathrm{POC} / \triangle \mathrm{PON}$ that is 6.74 (data not shown) in the ECS euphotic zone. This value is very close to the Redfield $\mathrm{C} / \mathrm{N}$ ratio and suggests the ratio (6.74) of biological uptake from DIC and DIN pools. However, the slope of $\triangle \mathrm{NDIC/}$ $\triangle$ NDIN (14.3, Fig. 11a) is nearly twice the ratio of $\triangle \mathrm{POC} / \triangle \mathrm{PON}$, implying that $\mathrm{DON}$ was preferentially decomposed and utilized biologically to overcome the over consumption of DIC to DIN. Although we do not measure $\triangle \mathrm{POC} / \triangle \mathrm{POP}$, we believe that a preferential decay of DOP over DOC is likely to occur and the released DIP is used for POM production, as justified from a greater value for the $\Delta$ NDIC/ $\triangle$ NDIP slope (129; Fig. 11b) than for the Redfield C:P ratio (106). Meanwhile, the large magnitude of $\Delta \mathrm{NDIC} /$ $\triangle$ NDIN may indicate that carbon exports from the euphotic zone may be underestimated if they are derived from nitrate uptake and scaling from the Redfield ratio (6.6).

\subsection{Degradation of $D O C$ and $D O P$}

Degradation rates of DOC and DOP are estimated from the decrease in concentration with
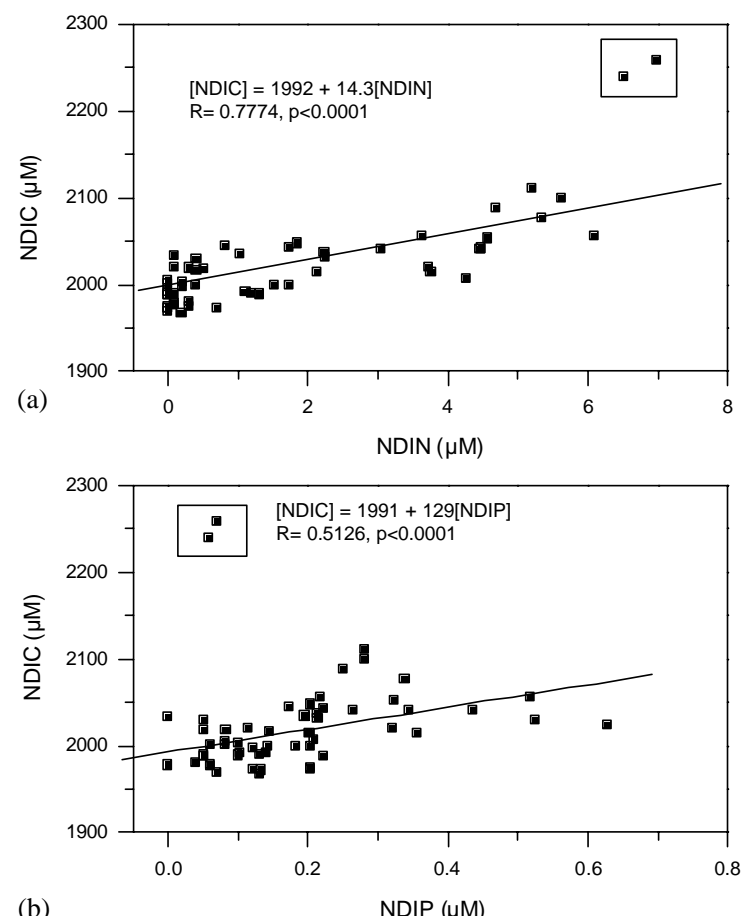

Fig. 11. Relation plots between NDIC (DIC normalized to salinity 35 ) and NDIN (a), and between NDIC and NDIP (b). 

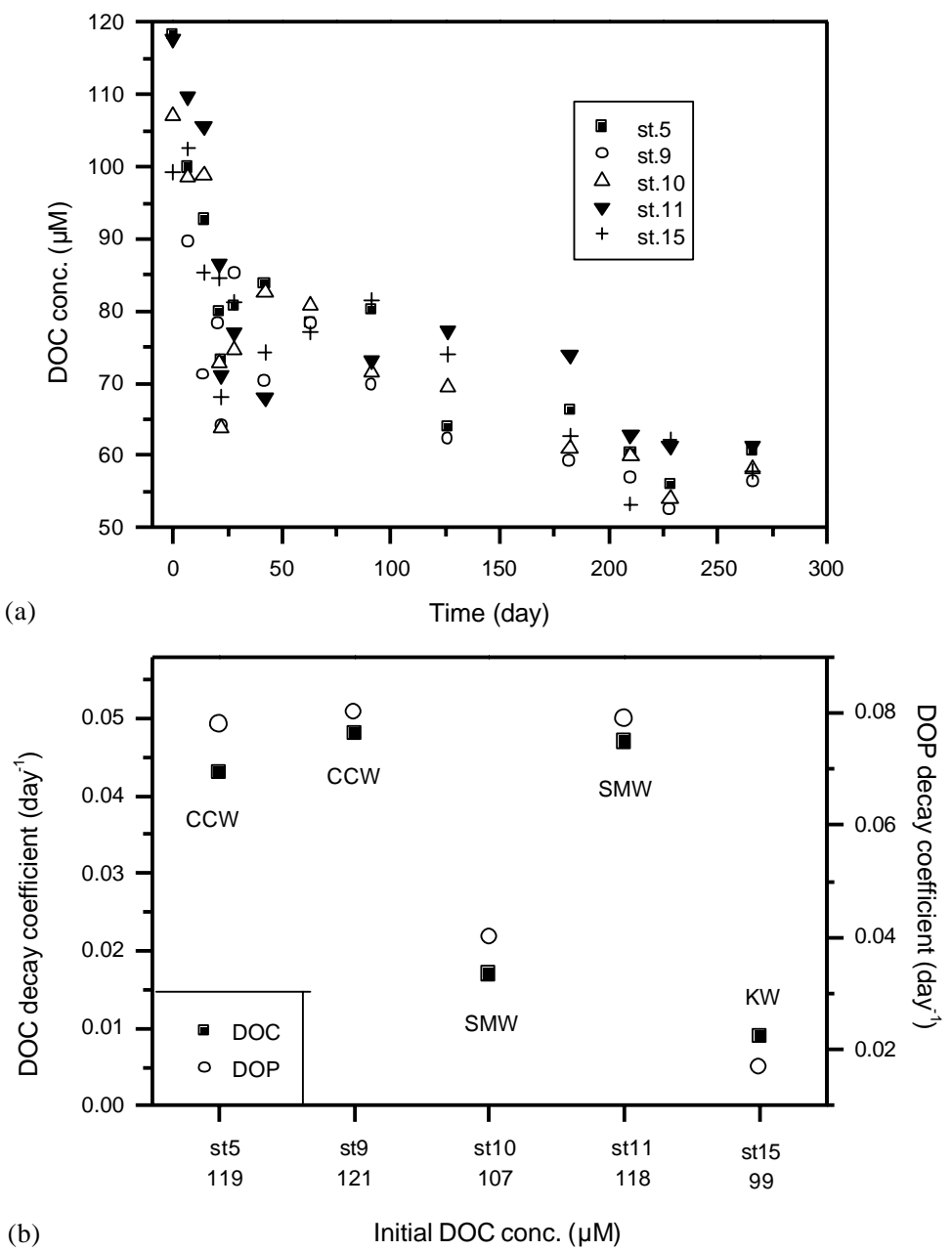

Fig. 12. Kinetics of DOC degradation for various waters during the course of incubation (a), and the decay coefficients of DOC and DOP for various waters (b).

incubation time. Fig. 12a shows that DOC degradation varies with water type and incubation time. The patterns of DOC decrease with time are similar for various waters, so the degradation rate for each water can be fitted and delineated well with the first order decay function, $C=C_{0} \mathrm{e}^{-k t}$, where $C_{0}$ is the initial concentration, $t$ is the incubation time and $k$ (decay coefficient) is the degradation rate. The DOC degradation rate is thus calculated as $0.043-0.048 \mathrm{~d}^{-1}$ for the CCW, $0.017-0.047 \mathrm{~d}^{-1}$ for the SMW and $0.009 \mathrm{~d}^{-1}$ for the KW (Fig. 12b). Apparently, the degradation rate is faster in the CCW than in the $\mathrm{KW}$, and the rate is also affected substantially by the initial concentration. Hopkinson et al. (1997) also reported a positive relationship between decay coefficient $\left(0-0.0025 \mathrm{~d}^{-1}\right)$ and initial DOC concentration $(50-91 \mu \mathrm{M})$ for seawater at the Georges Bank region. However, Kirchman et al. (1991) and Ogura (1972) obtained different rates of DOC decay from the North Atlantic $\left(0-0.4 \mathrm{~d}^{-1}\right)$ and the northern North Pacific $\left(0.005 \mathrm{~d}^{-1}\right)$, with a small difference of initial concentration. Variations in chemical composition may be responsible for such variable degradation rates. It may be argued that the degradation rate is not only affected by the initial concentration but also by the abundance of inorganic nutrients that may limit microbial 
activity during incubation. In fact, the degradation rate is correlated significantly with nitrate concentration $(R=0.873, p<0.001)$, as the $\mathrm{CCW}$ and the SMW are more enriched with nitrate than is the $\mathrm{KW}$. As a result, the DOC degradation rate is closely related to microbial turnover rates found in the ECS by Shiah et al. (2000). Despite the possible arguments that the degradation experiment conducted in bottles may have modified the in situ environment and biotic community, our degradation rates are within the ranges of previous findings (Ogura, 1972; Kirchman et al., 1991; Hopkinson et al., 1997) and can be used as an index of DOC decay in the ECS.

Three classes of DOC reactivity may be conceivable as DOC concentrations decrease rapidly during the first $40 \mathrm{~d}$ of incubation and then decrease gradually between 40 and $200 \mathrm{~d}$, followed by a final step with very slow degradation (Fig. 12a). DOC degradation rates of three classes are equivalent to $0.88,0.105$ and $<0.001 \mu \mathrm{M}$ $\mathrm{Cd}^{-1}$, respectively, if they are derived separately from a linear model of DOC degradation rate (slope of linear regression between DOC concentration and time). Accordingly, DOC may be regarded as labile, semi-labile and refractory with half-lives on the order of weeks, months and years, respectively. It is worth noting that the surface DOC may comprise largely recently produced components and their half-lives are shorter than those of deep water. As the ECS shelf water has a mean residence time on the order of $1 \mathrm{yr}(\mathrm{Li}, 1994$; Tsunogai et al., 1997; Peng et al., 1999), only a small fraction of DOC produced in situ may be able to escape from recycling on the shelf and be exported to the open ocean.

Degradation of DOP follows the patterns for DOC, but their decay coefficients are much greater than those of DOC (Fig. 12b). Little DOP remains for the incubation time longer than $60 \mathrm{~d}$. This is consistent with findings that DOP is much more labile than is DOC, revealed from stoichiometric patterns. It also can be inferred that DOP is primarily produced recently on the shelf and labile DOP may be recycled several times on the time frame of residence time of ECS shelf water. Degradation of DOP may make a significant contribution to primary production in the ECS.

\subsection{Cross-shelf exports of DOC, DON, and DOP}

It has been discussed that DOM inputs from the Changiiang runoff, the upwelling and sedimentary fluxes combined with that of in situ production may be recycled to a large extent in the ECS shelf, because most DOC half-lives are shorter than the mean residence time of shelf water. Understanding the cross-shelf exports of DOC, DON, and DOP is highly desirable as the exports may provide information about the role of shelves on the marine carbon cycles. Before such an attempt, a water budget from the ECS shelf should be clearly defined. Li (1994) used a salt balance in the box model to estimate the water exchange rate between the ECS shelf water and the KW as $2.2 \pm 0.9 \times 10^{4} \mathrm{~km}^{3} \mathrm{yr}^{-1}(0.70 \pm 0.29 \mathrm{~Sv})$. This rate is roughly 25 times the value of major river runoffs in the region. Using the similar model but separating the KW into the Kuroshio surface water, the Tropical Water and the Intermediate Water, Chen (1996) estimated the cross-shelf exchange of water as $-3.3 \times 10^{4} \mathrm{~km}^{3} \mathrm{yr}^{-1}$ $(1.05 \mathrm{~Sv})$ that is balanced by inputs of the Kuroshio surface water $\left(1.6 \times 10^{4} \mathrm{~km}^{3} \mathrm{yr}^{-1}\right.$, $0.51 \mathrm{~Sv})$ and the Kuroshio subsurface water $\left(1.7 \times 10^{4} \mathrm{~km}^{3} \mathrm{yr}^{-1}, \quad 0.54 \mathrm{~Sv}\right)$. This budget was recently verified by D.D. Sheu through rigorous modeling by using both salt and $\delta^{18} \mathrm{O}$ balances. The influxes of Kuroshio surface intrusion (0$50 \mathrm{~m})$ and subsurface upwelling $(50-150 \mathrm{~m})$ are calculated to be $0.58 \times 10^{4}(0.183 \mathrm{~Sv})$ and $1.54 \times 10^{4} \mathrm{~km}^{3} \mathrm{yr}^{-1}(0.487 \mathrm{~Sv})$, respectively. The inflow of Taiwan Strait Water is calculated to be $1.58 \times 10^{4} \mathrm{~km}^{3} \mathrm{yr}^{-1}(0.5 \mathrm{~Sv})$. The outflow of shelf water is therefore balanced by a rate of $3.83 \times 10^{4} \mathrm{~km}^{3} \mathrm{yr}^{-1}(1.22 \mathrm{~Sv})$. The water budget developed by D.D. Sheu (Table 2) is applied to model DOM budgets in the ECS.

Table 2 also illustrates DOC, DON, and DOP budgets in the ECS. Each flux of DOM is calculated from the water flux and the representative concentrations. The representative concentrations of DOC, DON, and DOP in the Kuroshio subsurface water, the Kuroshio surface water, the Taiwan Strait Water and the exported shelf water are determined from the relationship between DOM and salinity and $\delta^{18} \mathrm{O}$ in various water 
Table 2

Budgets of DOC, DON and DOP in the ECS Shelf

\begin{tabular}{|c|c|c|c|c|c|c|c|c|c|}
\hline Transport & Salinity & $\delta^{18} \mathrm{O}(\% 0)$ & $\begin{array}{l}\text { Water flux } \\
\left(\mathrm{m}^{3} \mathrm{~s}^{-1}\right)\end{array}$ & {$[\mathrm{DOC}](\mu \mathrm{M})$} & $\begin{array}{l}\text { DOC flux (Tg } \\
\left.\mathrm{C} \mathrm{yr}^{-1}\right)\end{array}$ & {$[\mathrm{DON}](\mu \mathrm{M})$} & $\begin{array}{l}\text { DON flux }(\mathrm{Gg} \\
\left.\mathrm{Nyr}^{-1}\right)\end{array}$ & {$[\mathrm{DOP}](\mu \mathrm{M})$} & $\begin{array}{l}\text { DOP flux (Gg } \\
\left.\mathrm{Pyr}^{-1}\right)\end{array}$ \\
\hline Input & & & & & & & & & \\
\hline $\begin{array}{l}\text { Kuroshio } \\
\text { subsurface } \\
\text { upwelling }\end{array}$ & 34.52 & 0.23 & $48.7 \times 10^{4}$ & $61.4 \pm 2.5$ & $11.4 \pm 0.5$ & $3.5 \pm 0.5$ & $754 \pm 107$ & $0.05 \pm 0.02$ & $25.4 \pm 9.5$ \\
\hline $\begin{array}{l}\text { Kuroshio } \\
\text { surface water } \\
\text { intrusion }\end{array}$ & 34.70 & 0.36 & $18.3 \times 10^{4}$ & $80 \pm 6$ & $5.5 \pm 0.4$ & $6.0 \pm 0.5$ & $485 \pm 40$ & $0.15 \pm 0.05$ & $27.5 \pm 9.5$ \\
\hline $\begin{array}{l}\text { Taiwan Strait } \\
\text { Water }\end{array}$ & 33.68 & -0.1 & $50.0 \times 10^{4}$ & $75 \pm 3$ & $14.1 \pm 0.6$ & $6.0 \pm 1$ & $1289 \pm 43$ & $0.16 \pm 0.06$ & $77.9 \pm 29$ \\
\hline $\begin{array}{l}\text { Changjiang } \\
\text { inflow }\end{array}$ & 0.18 & -8 & $3.44 \times 10^{4}$ & 143 & $1.86^{\mathrm{a}}$ & $14.5^{\mathrm{b}}$ & 221 & $0.6^{\mathrm{c}}$ & 18.6 \\
\hline $\begin{array}{l}\text { Precipitation } \\
\text { Total input }\end{array}$ & 0 & -7 & $\begin{array}{l}3.62 \times 10^{4} \\
124 \times 10^{4}\end{array}$ & $72 \pm 4^{d}$ & $\begin{array}{l}0.98 \pm 0.05 \\
33.8 \pm 0.9\end{array}$ & $7 \pm 2^{d}$ & $\begin{array}{l}112 \pm 28 \\
2861 \pm 125\end{array}$ & $0.3 \pm 0.1^{\mathrm{d}}$ & $\begin{array}{l}9.3 \pm 3.1 \\
158 \pm 30\end{array}$ \\
\hline $\begin{array}{l}\text { Output } \\
\text { Shelf water } \\
\text { export }\end{array}$ & 33.2 & 0.04 & $-121 \times 10^{4}$ & $78 \pm 3$ & $-35.7 \pm 1.2$ & $6 \pm 1$ & $-3205 \pm 532$ & $0.15 \pm 0.05$ & $-183 \pm 56$ \\
\hline $\begin{array}{l}\text { Evaporation } \\
\text { Total output }\end{array}$ & 0 & -9.5 & $\begin{array}{l}-3.09 \times 10^{4} \\
-124 \times 10^{4}\end{array}$ & 0 & $\begin{array}{l}0 \\
-35.7 \pm 1.2\end{array}$ & 0 & $\begin{array}{l}0 \\
-3205 \pm 532\end{array}$ & 0 & $\begin{array}{l}0 \\
-183 \pm 56\end{array}$ \\
\hline Net transport & & & 0 & & $-1.9 \pm 1.5$ & & $-344 \pm 546$ & & $-25 \pm 63$ \\
\hline
\end{tabular}


masses. Total inputs of DOC, DON, and DOP are largely derived from the Kuroshio subsurface water and the Taiwan Strait Water and only slightly contributed from river and rain inputs. The offshore transports of DOC, DON, and DOP are estimated from exchange rates of water and boundary concentrations for water with 33.2 salinity and $0.04 \delta^{18} \mathrm{O}$. With considering uncertainties associated with DOC, DON, and DOP fluxes, the total inputs are nearly balanced by the outputs. Otherwise, there are only small net outputs for DOC $\left(-1.9 \times 10^{12} \mathrm{~g} \mathrm{Cyr}^{-1}\right)$, DON $\left(-344 \times 10^{9} \mathrm{~g} \mathrm{Nyr}^{-1}\right)$, and DOP $\left(-25 \times 10^{9}\right.$ $\left.\mathrm{P} \mathrm{yr}^{-1}\right)$. The uncertainties of DON and DOP fluxes may be rather conservative because temporal variations are not considered in estimation. Therefore, it may be appropriate to regard the budgets as matching between total inputs and offshore outputs. This DOC budget is much smaller than that $\left(3-31 \times 10^{12} \mathrm{~g} \mathrm{Cyr}^{-1}\right)$ of shelf export from the Cape Hatteras into the North Atlantic basin (Bates and Hansell, 1999). Nevertheless, biological DOC production over the ECS shelf may be as large as $(39.1-65.2) \times 10^{12} \mathrm{~g} \mathrm{C} \mathrm{yr}^{-1}$ by assuming $30-50 \%$ of primary productivity $(397 \mathrm{mg}$ $\mathrm{C} \mathrm{m}^{-2} \mathrm{~d}^{-1}$ ) released as DOC in shelf water (Karl et al., 1998). These DOC, DON, and DOP produced recently over the shelf obviously do not contribute to shelf exports, they are apparently recyclable in the ECS shelf. This is consistent with the fact that the half-lives of labile and semi-labile DOC derived from recent production are much shorter than the mean residence time of shelf water.

The residence time $(\tau)$ of bulk DOC, DON, and DOP in the ECS shelf can be estimated from the DOM inventory and export rate $[\tau=(\mathrm{DOM}$ inventory $) /(\mathrm{DOM}$ export $)]$. The inventories of DOC, DON, and DOP are, respectively, $38.9 \times 10^{12} \mathrm{~g} \mathrm{C}, 3.15 \times 10^{12} \mathrm{~g} \mathrm{~N}$ and $0.167 \times 10^{12} \mathrm{~g}$ $\mathrm{P}$, which are estimated by integrating distributions over the shelf $\left(0.9 \times 10^{6} \mathrm{~km}^{2}\right)$. The export rate is $35.7 \pm 1.2 \times 10^{12} \mathrm{~g} \mathrm{Cyr}^{-1}$ for DOC, $3.20 \pm$ $0.53 \times 10^{12} \mathrm{~g} \mathrm{~N} \mathrm{yr}^{-1}$ for DON, and $0.18 \pm 0.05 \times$ $10^{12} \mathrm{~g} \mathrm{Pyr}^{-1}$ for DOP (Table 2). The residence time $(\tau)$ is therefore about $1.10,0.98$, and $0.92 \mathrm{yr}$ for DOC, DON, and DOP, respectively. The shorter residence time for DOP than DON and for DON than DOC is consistent with the fact that
DOP is preferentially degraded over DON and DON over DOC. Meanwhile, the residence time of DOC, DON, and DOP is on the range of residence time of shelf water reported previously (Li, 1994; Tsunogai et al., 1997; Peng et al., 1999). This also may result in small extents of net export for bulk DOM from the shelf.

It should be noted, however, that DOC input by upwelling from the Kuroshio subsurface water is actually refractory and largely resistant to biodegradation. As bio-reactive DOM is widely recognized for playing the key role in carbon cycling in the oceans (Carlson et al., 1994; Hansell and Carlson., 1998), the fate and budget of this DOM fraction in the ECS shelf should be examined. If $50 \mu \mathrm{M} \mathrm{C}$ is taken as the level of highly refractory pool in seawater (Fig. 11a) and $\frac{1}{3}$ of DOC concentration in river (or rain) water is regarded as bio-degradable (Ittekkot, 1988; Moran et al., 1999), then the net output of labile and semilabile DOC is estimated to be $3.8 \pm 0.6 \times 10^{12} \mathrm{~g}$

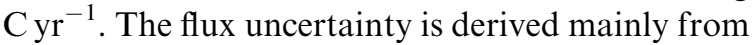
the concentration uncertainty of labile and semilabile DOC, which is approximated to $\frac{1}{3}$ uncertainty of bulk DOC flux. It may suggest that DOC produced recently can be potentially exported from the shelf with a magnitude less than 4.4 $(3.8+0.6) \times 10^{12} \mathrm{~g} \mathrm{C} \mathrm{yr}^{-1}$ (upper limit), which is just equivalent to $3.5 \% \mathrm{PP}$ in the ECS shelf. Alverez-Salgado et al. (2001) recently reported that the labile DOC produced in the coastal system may be exported significantly ( $\sim 20 \%$ net primary production) under the upwelling condition, but periodical transports of DOC varied hydrodynamically. However, most DOC produced through primary production may be recycled in the broad ECS shelf. Following the similar assumption, the level of refractory DON derived from the Kuroshio deep water is $3.0 \mu \mathrm{M} \mathrm{N}$ for the ECS seawater and about 5 and $10 \mu \mathrm{M} \mathrm{N}$ for rain and river waters, respectively. The potential net export of labile and semi-labile DON from the shelf would be $482 \pm 160 \times 10^{9} \mathrm{~g} \mathrm{~N} \mathrm{yr}^{-1}$. In case of DOP, the level of refractory DOP is about $0.05 \mu \mathrm{M}$ P for seawater, $0.4 \mu \mathrm{M}$ P for riverwater and $0.2 \mu \mathrm{M}$ P for rainwater. The potential net export of labile and semi-labile DOP is therefore estimated to be $37.5 \pm 18.5 \times 10^{9} \mathrm{~g} \mathrm{Pyr}^{-1}$. The ratios estimated 
from upper-bound exports are 7.9 for $\mathrm{DOC} / \mathrm{DON}$, 25 for DON/DOP and 202 for DOC/DOP, from which the values are much closer to the Redfield ratio than those of bulk elemental ratios. Consequently, the ECS shelf may be loosely regarded as potential sources for non-refractory DOC, DON and DOP. The exports may subsequently fuel the heterotrophic processes in the Kuroshio system and/or the North Pacific Ocean.

\section{Conclusion}

Distributions of DOC, DON and DOP vary spatially in the ECS. DOC concentrations are relatively high in the CCW $(85-120 \mu \mathrm{M})$ and the Kuroshio water $(75-85 \mu \mathrm{M})$, but low $(60-70 \mu \mathrm{M})$ around the shelf break where the Kuroshio upwelling occurs. Temporal variations are only significant for the $\mathrm{CCW}$ close to the Changjiang plume in which the greater concentration occurs during summer and autumn than during spring and winter. Spatial variations of DON and DOP are less pronounced than that of DOC. Vertical gradients of DOC, DON, and DOP concentrations were relatively strong in the thermocline of $\mathrm{KW}$ but weak in the ECS shelf. Stoichiometric ratios of DOC/DON, DON/DOP, and DOC/DOP generally increase with depth and are much greater than the Redfield ratio, indicating the preferential decay of DOP over DON and DON over DOC. Mineralization rates of DOC and DOP are much greater in the ECS shelf than in the KW and those previous reports from open oceans, which also suggest a different lability of DOC or DOP in various waters of the ECS. The residence time estimated for shelf DOC, DON, and DOP is close to that of shelf water, implying little DOM escaped from recycling in the shelf. Thus, total inputs are nearly balanced by outputs in the shelf for bulk DOC, DON, and DOP but potential net exports across the shelf are obtained for degradable DOM.

\section{Acknowledgements}

The authors thank the National Science Council, Republic of China for financially supporting this research under Contract Nos. NSC 87-2611M110-007-K2, NSC 88-2621-M110-006-K2 and NSC 89-2611-M110-003-K2. The captain and crew members on the Ocean Researcher $I$ are commended for their assistance during sampling. We are grateful for anonymous reviewers' comments to improve the manuscript. This research is a contribution to the KEEP study, a recognized program of the JGOFS.

\section{References}

Abell, J., Emerson, S., Renaud, P., 2000. Distributions of TOP, TON and TOC in the North Pacific subtropical gyre: implications for nutrient supply in the surface ocean and remineralization in the upper thermocline. Journal of Marine Research 58, 203-222.

Alverez-Salgado, X.A., Gago, J., Miguez, B.M., Perez, F.F., 2001. Net ecosystem production of dissolved organic carbon in a coastal upwelling system: the Ria de Vigo, Iberian margin of the North Atlantic. Limnology and Oceanography 46 (1), 135-147.

Anderson, L.A., Williams, P.J.leB., 1998. Modelling of seasonal cycling of dissolved organic carbon at station E1 in the English Channel. Estuarine, Coastal and Shelf Science 46, 93-109.

Bates, N.R., Hansell, D.A., 1999. A high resolution study of surface layer hydrographic and biogeochemical properties between Chesapeake Bay and Bermuda. Marine Chemistry 67, 1-16

Beardsley, R.C., Limeburner, R., Yu, H., Cannon, G.A., 1985. Discharge of Changjiang (Yangtze River) into the East China sea. Continental Shelf Research 4, 57-76.

Benner, R., Strom, M., 1993. A critical evaluation of the analytical blank associated with DOC measurements by high-temperature catalytic oxidation. Marine Chemistry 41, 153-160.

Biscaye, P.E., Anderson, R.F., 1994. Fluxes of particulate matter on the slope of the southern Middle Atlantic Bight: SEEP II. Deep-Sea Research II 41, 459-509.

Carlson, C.A., Ducklow, H.W., Michaels, A.F., 1994. Annual flux of dissolved organic carbon from the euphotic zone in the northwestern Sargasso Sea. Nature 371, 405-408.

Cauwet, G., Mackenzie, F.T., 1993. Carbon inputs and distribution in estuaries of turbid rivers: the Yangtze and Yellow rivers (China). Marine Chemistry 43, 235-246.

Chen, C.T.A., 1996. The Kuroshio intermediate water is the major source of nutrients on the East China Sea continental shelf. Oceanologica Acta 19, 523-527.

Chen, R.F., Fry, B., Hopkinson, C.S., Repeta, D.J., Peltzer, E.T., 1996. Dissolved organic carbon on Georges Bank. Continental Shelf Research 16, 409-420.

Chen, Y.-L., Lu, H.-B., Shiah, F.-K., Gong, G.-C., Liu, K.-K., Kanda, J., 1999. New production and F-ratio on the 
continental shelf of the East China sea: comparisons between nitrate inputs from the subsurface Kuroshio current and the Changjiang river. Estuarine, Coastal and Shelf Science 48, 59-75.

Chern, C.-S., Wang, J., 1990. On the mixing of waters at a northern offshore area of Taiwan. Terrestrial, Atmospheric and Oceanic Sciences 1, 297-306.

Connolly, J.P., Coffin, R.P., Landeck, R.E., 1992. Modeling carbon utilization by bacteria in natural water systems. In: Hurst, C.J. (Ed.), Modeling the Metabolic and Physiologic Activities of Micro-organisms. Wiley, New York, pp. 249-276.

Gong, G.-C., 1992. Chemical hydrography of the Kuroshio front in the sea northeast of Taiwan. Ph.D. dissertation, Institute of Oceanography, National Taiwan University, p. 204.

Gong, G.-C., Liu, K.K., 1995. Summer time hydrography and control of nutrient distribution in the East China Sea. In: Tsunogai, S., Iseki, K., Koike, T., Oba, T. (Eds.), Global Fluxes of Carbon and its Related Substances in the Coastal Sea-Ocean-Atmosphere System. M \& J Internations, Yokohama, Japan, pp. 46-52.

Gong, G.-C., Chen Lee, Y.-L., Liu, K.-K., 1996. Chemical hydrography and chlorophyll a distribution in the East China Sea in summer: implications in nutrient dynamics. Continental Shelf Research 16, 1561-1590.

Gong, G.-C., Wen, Y.-H., Wang, B.-W., Lin, G.-J., 2003. Seasonal variation of chlorophyll $a$ concentration, primary production and environmental conditions in the subtropical East China Sea. Deep-Sea Research II, this issue (doi: 10.1016/S0967-0645(03)00019-5).

Gong, G.-C., Shiah, F.-K., Liu, K.-K., Wen, Y.-H., Liang, M.-H., 2000. Spatial and temporal variation of chlorophyll a, primary productivity and chemical hydrography in the southern East China sea. Continental Shelf Research 20, 411-436.

Grasshoff, K., Ehrhardt, M., Kremling, K. (Eds.), 1983. Methods of Seawater Analysis. Verlag Chemie, Weinheim, p. 419.

Guo, L., Santschi, P.H., Warnken, K.W., 1995. Dynamics of dissolved organic carbon [DOC] in oceanic environments. Limnology and Oceanography 40, 1392-1403.

Hansell, D.A., Carlson, C.A., 1998. Net community production of dissolved organic carbon. Global Biogeochemical Cycles 12, 443-453.

Hopkinson Jr., C.S., Fry, B., Nolin, A.L., 1997. Stoichiometry of dissolved organic matter dynamics on the continental shelf of the northeastern USA. Continental Shelf Research 17, 473-489.

Hung, J.-J., Lin, P.-L., 1995. Distribution of dissolved organic carbon in the continental margin off Northern Taiwan. Terrestrial, Atmospheric and Oceanic Sciences 6, 13-26.

Hung, J.-J., Lin, P.-L., Liu, K.-K., 2000. Dissolved and particulate carbon in the southern East China Sea. Continental Shelf Research 20, 545-569.

Ittekkot, V., 1988. Global trends in the nature of organic matter in river suspensions. Nature 332, 436-438.
Jackson, G.A., Williams, P.M., 1985. Importance of dissolved organic nitrogen and phosphorus to biological nutrient cycling. Deep-Sea Research I 32, 223-235.

Karl, D.M., Hebel, D.V., Bjorkman, K., Letelier, R.M., 1998. The role of dissolved organic matter release in the productivity of the oligotrophic North Pacific ocean. Limnology and Oceanography 43 (6), 1270-1286.

Kirchman, D., Suzuki, Y., Garside, C., Ducklow, H., 1991. High turnover rates of dissolved organic carbon during a spring phytoplankton bloom. Nature 32, 612-614.

Li, Y.H., 1994. Material exchange between the East China Sea and the Kuroshio current. Terrestrial, Atmospheric and Oceanic Sciences 5, 625-631.

Lin, Y., Tang, R., Li, Y., 1996. Effect of biogeochemical variations of $\mathrm{C}, \mathrm{N}$ and $\mathrm{P}$ on flocculation and settling of suspended particles in the Changjiang Estuary. In: Zhang, J. (Ed.), Biogeochemical Studies on Chinese Major EstuariesElement Transfer and Environment. China Ocean Press, Beijing, pp. 160-168.

Liu, K.-K., Gong, G.-C., Lin, S., Yang, C.-Y., Wei, C.-L., Pai, S.-C., Wu, C.-K., 1992. The year-round upwelling at the shelf break near the northern tip of Taiwan as evidenced by chemical hydrography. Terrestrial, Atmospheric and Oceanic Sciences 3, 243-276.

Maita, Y., Yanada, M., 1990. Vertical distribution of total dissolved nitrogen and dissolved organic nitrogen in seawater. Geochemical Journal 24, 245-254.

Milliman, J.D., Meade, R.H., 1983. Worldwide delivery of river sediment to the oceans. Journal of Geology 91, 1-21.

Moran, M.A., Sheldon Jr., W.M., Sheldon, J.E., 1999. Biodegradation of riverine dissolved organic carbon in five estuaries of the southeastern United States. Estuaries 22, 55-64.

Norrman, B., Zweiffel, U., Hopkinson, C., Fry, B., 1995. Production and utilization of dissolved organic carbon during an experimental diatom bloom. Limnology and Oceanography 40, 898-907.

Nitani, H., 1972. The beginning of the Kuroshio. In: Stommel, h., Yoshida, K. (Eds.), Kuroshio. University of Tokyo Press, Japan, pp. 129-156.

Ogura, N., 1972. Rate and extent of decomposition of dissolved organic matter in surface seawater. Marine Biology 13, 89-93.

Orrett, K., Karl, D.M., 1987. Dissolved organic phosphorus production in surface seawater. Limnology and Oceanography 32, 383-395.

Pai, S.-C., Yang, C.-C., 1990. Effects of acidity and molybdate concentration on the kinetics of the formation of the phosphoantimonylmolybdnum blue complex. Analytica Chemica Acta 229, 115-120.

Peng, T.-H., Hung, J.-J., Wanninkhof, R., Millero, F.J., 1999. Carbon budget in the East China Sea in spring. Tellus B 51, 531-540.

Ridal, J.J., Moore, R.M., 1990. A re-examination of the measurement of dissolved organic phosphorus in seawater. Marine Chemistry 29, 19-31.

Ridal, J.J., Moore, R.M., 1992. Dissolved organic phosphorus concentrations in the northeast subarctic Pacific Ocean. Limnology and Oceanography 37, 1067-1075. 
Sanders, R., Jickells, T., 2000. Total organic nutrients in Drake Passage. Deep-Sea Research I 47, 997-1014.

Sharp, J.H., 1993. The dissolved organic carbon controversy: an uptake. Oceanography 6, 45-60.

Shiah, F.-K., Gong, G.-C., Liu, K.-K., 1999. Temperature vs. substrate limitation of heterotrophic bacterioplankton production across trophic and temperature gradient in the East China Sea. Aquatic Microbial Ecology 17 (3), 247-254.

Shiah, F.-K., Liu, K.-K., Kao, S.-J., Gong, G.-C., 2000. The coupling of bacterial production and hydrography in the southern East China Sea: spatial patterns in spring and fall. Continental Shelf Research 20, 459-477.

Thomas, W.H., Renger, E.H., Dodson, A.N., 1971. Near surface organic nitrogen in the Eastern Tropical Pacific Ocean. Deep-Sea Research I 18, 65-71.

Thomas, H., Ittekkot, V., Osterroht, C., Schneider, B., 1999. Preferential recycling of nutrients-the Ocean's way to increase new production and to pass nutrient limitation. Limnology and Oceanography 44 (8), 1999-2004.

Tsunogai, S., Watanabe, S., Nakamura, J., Ono, T., Sato, T., 1997. A preliminary study of carbon system in the East China Sea. Journal of Oceanography 53, 9-17.

Vidal, M., Duarte, C.M., Agusti, S., 1999. Dissolved organic nitrogen and phosphorus pools and fluxes in the central Atlantic Ocean. Limnology and Oceanography 44, 105-115.
Walsh, T.W., 1989. Total dissolved nitrogen in the seawater: a new-high-temperature combustion method and a comparison with photo-oxidation. Marine Chemistry 26, 295-311.

Walsh, J.J., 1991. Importance of continental margins in the marine biogeochemical cycling of Carbon and Nitrogen. Nature 350, 53-55.

Walsh, J.J., Biscaye, P.E., Csanady, G.T., 1988. The Shelf Edge Exchange Processes [SEEP] experiment: hypotheses and highlights. Continental Shelf Research 8, 435-456.

Williams, P.M., Carlucci, A.F., Olson, R., 1980. A deep profile of some biologically important properties in the central North Pacific gyre. Oceanologica Acta 3, 471-476.

Wollast, R., 1991. The coastal organic carbon cycles: fluxes, sources, and sinks. In: Wollast, R., Mackenzie, F.T., Chou, L. (Eds.), Interactions of C, N, and S Biogeochemical Cycles and Global Change. Springer, Berlin, pp. 195-210.

Wong, G.T.F., Pai, S.C., Liu, K.K., Chen, C.T.A., 1991. Variability of the chemical hydrography at the frontal region between the East China Sea and the Kuroshio northeast of Taiwan. Estuarine, Coastal and Shelf Science 33, 105-120.

Wotton, R.S., 1994. Particulate and dissolved organic matter as food. In: Wotton, R.S. (Ed.), The Biology of Particles in Aquatic Systems. Lewis Publishers, Boca Raton, pp. 235-288. 